\title{
科学的エビデンスを主体としたスポーツの在り方
}

\section{1 現状及び問題点}

スポーツの語源は15世紀以前のラテン語 “deportare”、すなわち「気分転換」にあるが、現代ではもっ ぱら、激しい肉体活動や競技を意味するようになっている。それは、ごく限られた環境の子どもたちし かオリンピックやパラリンピックの選手を目指せないという日本の現状に、象徵的に示されている。選 手経験のあるスポーツ関係者や保護者は、その経験ゆえに、幼少期から厳しい練習をしなければ一流に なれないという気持ちが強く、よい成果を出すには長時間の練習が必要だと考えがちである。科学的工 ビデンスではなく、自身の経験を重視してきたことで、スポーツ界は、指導者の身体的・精神的暴力と いったハラスメントを生みやすい風土にある。閉じた世界に共通して起こりがちなハラスメントに対し ては、国を挙げてその削隇に取り組まなければならない。昨今では、 e スポーツをはじめ、従来のスポー ツ概念や認識とは異なる活動がスポーツ界自体を押し広げつつある。変化し続ける環境の中で、スポー ツと人間の関係を見直し、科学的なエビデンスに基づいて、スポーツ及びその価值を再定義する時期に きている。このような状況の中、平成 30 年 11 月 15 日、スポーツ庁長官から日本学術会議会長に対し、「科 学的エビデンスに基づく「スポーツの価值」の普及の在り方に関する審議について」と題する審議依頼 がなされた。これを受けて、日本学術会議は、同年11月29日に「科学的エビデンスに基づく「スポー ツの価值」の普及の在り方に関する委員会」を設置し、審議を開始した。委員会では、日本のスポーツ の現状を歴史的背景とともに俯瞰的に把握しながら、「スポーツの価值」を検討するための科学的エビ デンスを多方面から収集し、それに基づいてスポーツの今日的意義を考える重要性などが指摘された。 議論の内容が審議依頼を大きく超えたことから、本委員会では、これまでの議論をスポーツ庁長官への 「回答」とするとともに、政策提言としてもとりまとめ、ここに発出する次第である。

\section{2 提言の内容}

本提言は、科学の視点からスポーツの在り方を検討した結果である。日本学術会議は、今後も引き続き、 スポーツ庁はじめ、関係者との対話を進めながら、継続的に政策提言を行い、スポーツを通して得られ る多様な価值を国民の人生に活かすことに貢献していく。

（1）科学的エビデンスの収集とその包括的分析を可能とする体制の整備

スポーツの価值は、競技における勝敗のみで決まるものではなく、また人生のある一瞬に凝縮される 
ものでもない。スポーツの価值を捉え直し、それを社会に資するものへと向けるためには、科学的エビ デンスに基づく政策を明確化し、スポーツの指導や練習の方法を変えていくことが急務である。その実 現のためには、科学的エビデンスの取得と収集、分析を進め、科学技術の進展に見合ったデータの有効 活用が必至である。取得されたデー夕は国立スポーツ科学センターに一元化し、必要とする関係者間で 広く共有して、包括的分析を可能とする開かれた体制整備が必要である。

（2）時代変化を意識したスポーツ政策の決定

スポーツは歴史とともに変化する。歴史的背景を踏まえつつ、時代の変化に応じて個人と社会にスポー ツの価值を提供できる仕組みには、常に試行錯誤が求められる。その際には科学的エビデンスに基づく ことが重要だが、完璧なエビデンスが常にあるわけではなく、経験に基づく知見を科学的に精査して一 定の価值を見いだし、科学的エビデンスと調和させることが必要となる。スポーツ庁は、人生を通して 得られるスポーツの価值に目を向け、行き過ぎた身体改造などがもたらす倫理的問題や、アスリート引 退後の精神障害、若年層を中心に普及しつつある e スポーツが内包するゲームへの依存症など、スポー ツの多様な側面を考慮してスポーツ政策を決定していくことが不可欠である。

（3）多様な人々の参画による生涯を通した多様なスポーツ実践のための環境づくり

幼少期からの多様なスポーツ経験が脳の発達や生涯にわたるスポーツ実践につながり、高齢期に至る あらゆる年齢層でのスポーツ実践が健康保持や脳機能維持、老化防止に寄与する可能性が高いことが報 告されている。特に大規模災害や感染症拡大などの非常時には、スポーツを含む生活のバランスを保つ 努力が必要である。スポーツを通して得られる価值が社会に資するものとなるためには、障害者を含む 多様な人々の参画が必要であり、多様性を包含する障害者スポーツから学ぶことは大きい。よって文部 科学省は、幼少期から高齢期までの生涯を通して、多様な人々が参画できる多様なスポーツ経験を支え、 科学的エビデンスに基づく環境づくりと教育体制の整備を進める必要がある。

（4）スポーツにおける暴力の削減と最小化

現代のスポーツは競技の意味合いが強く、「相手を倒す」ことが目的化することから暴力との親和性 が高くなりがちであるため、暴力の根絶は容易ではない。スポーツにおける暴力には指導者の影響が大 きいため、科学的エビデンスに基づく指導方法の開発を進め、指導者の目を、その指導方法の活用に向 けることが暴力防止に有用である。指導方法の開発には、スポーツ科学だけでなく、脳科学や情報学な どとの学際的研究として進めることが望ましい。スポーツ庁はそのための政策を明確に示し、スポーツ 関係機関と関係者にその実行を促すとともに、生涯を通して得られるスポーツの価值を国民と広く共有 し、選手と指導者を行き過ぎた競争から解放することも必要である。 